\title{
$\mathrm{LR}=$ INTERNATIONAL JOURNAL OF ACADEMIC \\ HUMAN RESOURCE
MAAAGEMENACADEMIC
RESEARCH SOCIETY

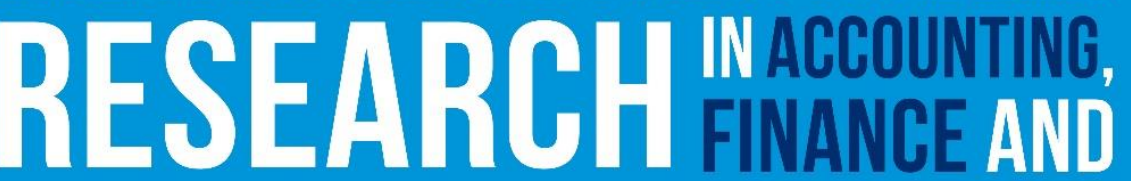

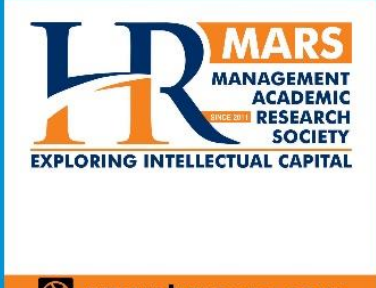

\&ww.hrmars.com

ISSN: 2225-8329

\section{Electronic Tax System and Internally Generated Revenue in the Nigerian Emerging Economy: The Study of Ebonyi State Board of Internal Revenue}

\author{
Oketa E.Chiamaka, Nwamgbebu P.Obinna, Nkwede E. Friday, Chikaodili N. \\ Oraekwuotu
}

To Link this Article: http://dx.doi.org/10.6007/IJARAFMS/v11-i2/10312 DOI:10.6007/IJARAFMS /v11-i2/10312

Received: 08 April 2021, Revised: 10 May 2021, Accepted: 27 May 2021

Published Online: 19 June 2021

In-Text Citation: (Chiamaka et al., 2021)

To Cite this Article: Chiamaka, E. O., Obinna, P. N., Friday, N. E., \& Oraekwuotu, C. N. (2021). Electronic Tax System and Internally Generated Revenue in the Nigerian Emerging Economy: The Study of Ebonyi State Board of Internal Revenue. International Journal of Academic Research in Accounting Finance and Management Sciences, 11(2), 123-149.

\section{Copyright: (c) 2021 The Author(s)}

Published by Human Resource Management Academic Research Society (www.hrmars.com)

This article is published under the Creative Commons Attribution (CC BY 4.0) license. Anyone may reproduce, distribute, translate and create derivative works of this article (for both commercial and non-commercial purposes), subject to full attribution to the original publication and authors. The full terms of this license may be seen

at: http://creativecommons.org/licences/by/4.0/legalcode

\section{Vol. 11, No. 2, 2021, Pg. 123 - 149}




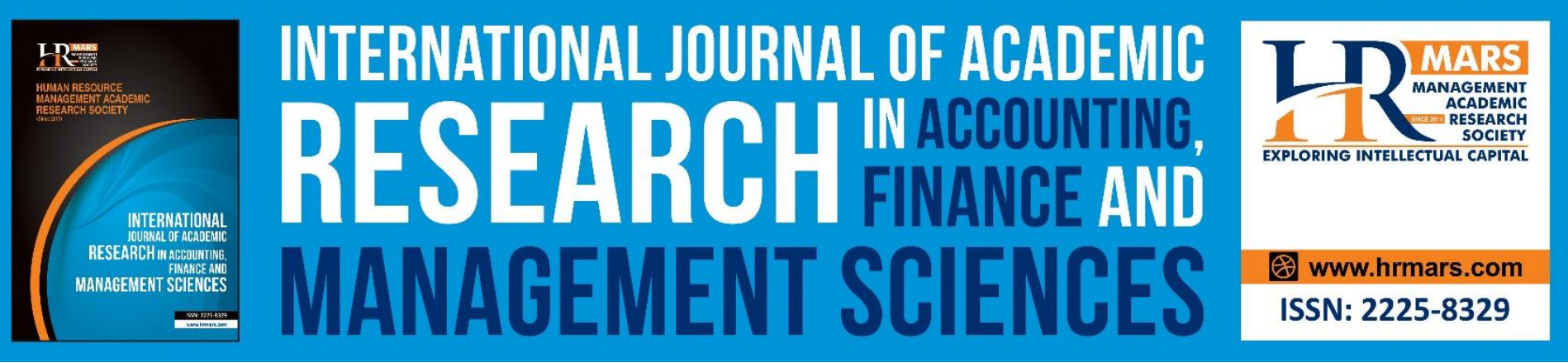

\title{
Electronic Tax System and Internally Generated Revenue in the Nigerian Emerging Economy: The Study of Ebonyi State Board of Internal Revenue
}

\author{
Oketa E.Chiamaka \\ Department of Accountancy, Alex Ekwueme Federal University Ndufi-alike IkwoEbonyi State Nigeria \\ Email: nwuzorchiamaka@gmail.com \\ Nwamgbebu P.Obinna \\ Department of accountancy, Ebonyi State University, Abakiki, Nigeria \\ Email: obinnamgbabu@yahoo.com \\ Nkwede E. Friday \\ Department of Banking and Finance Ebonyi State University, Abakiki, Nigeria \\ Email: drnkwede@gmail.com
}

\section{Chikaodili N. Oraekwuotu}

Alex Ekwueme Federal University Ndufi-alike Ikwo, Ebonyi State, Nigeria

Email: chikankemo@gmail.com

\begin{abstract}
This study examined the effect of electronic tax system on the internally generated revenue in the Nigerian emerging economy, using Ebonyi State board of internal revenue as the case in point. To achieve this objective, electronic tax registration, electronic filing of tax returns and electronic payment of tax were used as proxies for electronic tax system. This study was anchored on expediency theory of taxation and technology acceptance model. A quantitative cross-sectional survey data based on 94 valid responses extracted from 124 qualified and experienced respondents from Ebonyi State board of internal revenue formed the final database used in the quantitative analysis of the study. Findings reveal that out the major variables examined, electronic tax registration and electronic filing of tax returns affect internally generated revenue in Ebonyi State and by extension, the Nigerian emerging economy. Electronic tax payment does not statistically show significant effect on the internally generated revenue of state. The study therefore recommends that Ebonyi State board of internal revenue and by extension the Nigerian tax system should adopt a user friendly electronic tax system that can make electronic tax filing and payment easy for the taxpayers.
\end{abstract}


INTERNATIONAL JOURNAL OF ACADEMIC RESEARCH IN ACCOUNTING, FINANCE AND MANAGEMENT SCIENCES

Vol. 11, No. 2, 2021, E-ISSN: 2225-8329 ๑ 2021 HRMARS

Keywords: Revenue, Electronic Tax, Electronic Tax Payment, Electronic Tax System.

\section{Introduction}

There has been unprecedented advancement in technology in the last ten decades, to the extent that several roles that were hitherto played by man manually have been taken over by computer. To remain competitive and viable, therefore most governments, organizations, businesses and people have adopted technological systems and the internet of thing in various businesses. The technology adoption increased the advancement in the growth of the concepts of e-commerce and e-governance including tax administrators all over the world are not left out as it become necessary to use computer systems and networks in the process of tax registration, filing of tax returns and payment of taxes (Newman and Eghosa, 2019).Technology has influenced lives in many ways and continues to change the way of doing things from the simple day to day activities to the complex and less routine tasks. The impact of technology can be seen and felt in every area of lives from commerce to entertainment, education, communications, healthcare, defense and taxation (PWC, 2013).

In the area of governance, many developed and developing economies around the world have experimented and proven that no nation can truly develop without developing its technology-based tax system; hence the primary function of a good tax system is to raise enough revenue to finance essential expenditures on the goods and services provided by government (Emmanuel, 2010). Therefore, a high lucrative means of generating the amount of revenue needed for providing the necessary infrastructure for our country through tax is no doubt by a well-structured tax system based on technology.

However, Nigeria is yet to reap the full benefit of electronic-based taxation system as the case in developed countries of the world (Eneojo and Gabriel, 2014).Uremadu and Ndulue (2011), observed that tax revenue in Nigeria accounts for a small proportion of total government revenue over the years compared with the bulk of revenue needed for developmental purposes that is derived from oil. Chandler (2013) also observed that today's policymakers are still grappling with the questions of effective tax administration leading to adequate tax revenue. Enahoro and Olabisi (2012),corroborate this view when they stated that there is a huge scale of corrupt practices prevalent in emerging economy such as Nigeria tax administrative system, which tells to a reasonable extent that the economy is at a disadvantaged position. Consequently, Nigerian tax system over the years has not been able to reach the expected objectives as a result of these setbacks and challenges, some of which include multiplicity of taxes, tax evasion, corruption, non-compliance with relevant tax laws, poor information base and records keeping. It is the view of some scholars that the loss of revenue caused by widespread tax evasion and tax avoidance in Nigeria is due to inefficient and inept tax administration. For instance, Angahar and Alfred (2012) opined that the machinery and procedures for implementing a good tax system in Nigeria are inadequate, hence tax evasion and avoidance of the self-employed individuals and organizations whose data base are not captured in the relevant tax authority's data system poses a great challenge and impediment to national economic growth. James and Moses (2012) corroborate this view when they stated that the prevalence of tax evasion in the Nigerian tax system, has curtailed the amount of revenue collected from tax income, which in no doubt has effect on the governance expenditure. 
INTERNATIONAL JOURNAL OF ACADEMIC RESEARCH IN ACCOUNTING, FINANCE AND MANAGEMENT SCIENCES

Vol. 11, No. 2, 2021, E-ISSN: 2225-8329 @ 2021 HRMARS

Consequently, the rationale for the adoption of electronic tax system in Nigeria came as a result of the invitation of the officials of International Monetary Fund (IMF) to appraise the Nigerian tax system in line with the global standards. Upon a critical scrutiny of the Nigerian tax system, the IMF recommended the modernization of the Federal Inland Revenue Service (FIRS) for it to remain virile and relevant amidst economic realities. In line with the recommendations of the International Monetary Fund (IMF), the FIRS adopted a seven fold programme of reforms which included reengineering and automating tax collection and tax administration generally. It has been observed that in most countries where tax revenues significantly constitute a major part of the economy's revenue, they have been using electronic tax system for years (Umenweke and Ifedora, 2016).

For the purpose of clarity of the concept within the background; electronic tax system is the integration of information technology (IT) into tax administration in the form of electronic-tax (E-Tax). The use of IT to aid tax administration is the initiative that gave birth to the popular E-tax system. This is a master tool in combating the challenges of any tax system as it provides information, education and support to taxpayers and facilitates compliance and administration. It should be clear, however, that E-tax system do more than provide information, education and assistance to taxpayers due to its unique components such as Electronic Tax Registration, Electronic Tax Filing and Electronic Tax Payment, it also guarantees reduced cost of administering taxes. Electronic tax system provides convenience to taxpayers for tax assessment and payment (Agrawal, 2016). This convenience can serve as a key driver for e-filing adoption especially in developing countries like Nigeria. Electronic tax system provides many aspects of convenience to taxpayers, for example, tax filing can be conducted at any time, any location, easy use of system, easy search of information and other online transactions that are not available in the traditional channels (Ndayisenga and Shukla, 2016). It also offers flexibility of time, reduces calculation errors on tax return forms to the taxpayers, taxpayers privacy and security (Agrawal, 2006). Furthermore, electronic tax system minimizes the work load of tax authorities and operational cost due to submission of tax returns on a paperless environment. It also reduces the costs of processing, storing and handling of tax return (Jayakumar and Nagalakshmi, 2006).

One of the major challenges of Ebonyi State board of internal revenue (EBSBIR) is the issue of tax evasion and avoidance which most times is as a result of corruption. This can be seen in the form of bribery by the taxpayers to the tax officials for reduction in the amount of tax to be paid or absolute non-payment of tax, patronage/nepotism, collusion between taxpayers and tax officers. Other major problems with the traditional system of taxation in Ebonyi State board of internal revenue are the issues of lack of tax statistical data or poor data base due to its manual nature, poor records keeping of the available information they have which has resulted to missing files, torn documents, multiplicity of taxes, poor tax administration, inability of the state government to prioritize tax efforts which have all resulted to very low tax yield

However, in a bid to improve on tax revenue, the EBSBIR in 2013 in line with the Federal Government adopted electronic tax system (Revo-tax) and implemented it in the year 2015. This electronic tax system, revotax, is provided by an independent ICT consultants called APPMART Limited. When effectively implemented, it is aimed at curtailing the loopholes, weaknesses and problems associated with the manual system of taxation in EBSBIR, thereby eliminating physical contacts between the taxpayers and tax officials and increasing her revenue generation.

Electronic registrations, electronic filing of tax returns and electronic tax payments, provide adequate tax records for easy communication of information and efficiently minimize cost of administration so 
INTERNATIONAL JOURNAL OF ACADEMIC RESEARCH IN ACCOUNTING, FINANCE AND MANAGEMENT SCIENCES

Vol. 11, No. 2, 2021, E-ISSN: 2225-8329 ๑ 2021 HRMARS

as to boost her internal revenue generation. Extant studies to the best our knowledge focused on examining the impact of e-taxation on revenue generation in Nigeria (Eneojo and Gabriel, 2014; Leyira, Chukwuma and Asia, 2012). Electronic tax system has been in operation in Ebonyi State since 2015 without any assessment of its effectiveness. Currently and to the best of the researcher's knowledge, there is no existing study that has empirically shown the extent to which the new technology has affected tax revenue in Ebonyi State. It is to bridge this gap that the study has become highly imperative.

\section{Literature Review}

This section comprises both the conceptual review, empirical review and the theoretical review.

\section{Conceptual review}

The modern tax administration seeks to focus on three key objectives: facilitating voluntary compliance, providing adequate tax records for easy communication of information and efficiently minimizing cost of collection (Oseni, 2015). This serves as the main function which led to the prevalent use of IT systems in tax administration. The adoption of information technology in the enforcement of core tax processes such as registration, filing of returns, payment and general maintenance of database brought about what is now known as an electronic based tax system popularly referred to as e-tax. Therefore, electronic tax system is defined as the automation of core tax processes which offers electronic registration, filing and payment as well as education and information to taxpayers. Broadly, the electronic tax system is a comprehensive internet portal that forms a suite of secure self-service options to taxpayers, may provide a single point for information and action, and is typically available 24 hours a day and 7 days a week, and does not require intervention from tax administrative staff.

The current economic situation in Nigeria has necessitated the need for government to embark on aggressive revenue drive that will enable the discharge of numerous duties to the citizens. With the intended shift to non-oil sources of income, taxation remains an unswerving tool for government to achieve this objective (Ajape, Afara and Uthman, 2017). Taxation is seen as a compulsory contribution levied by the government on personal income and business profits or added to the cost of some goods, services and transactions (Majura, 2013). According to Holban (2007), taxation is expected to play three significant roles: generation of sufficient funds for financing public services and social transfers; provision of incentives for more employment and efficient use of natural resources; reallocation of income. As so much is expected from taxation, Nigeria, like other economies of the world follows the path of continuous tax reform to cope with the global economic realities.

Tax experts and administrators have advocated for technology-driven tax system to expand the country's tax base, achieve economic diversification away from the oil revenue, and enhance the delivery of public services and fiscal propriety (Harrisson and Nahashon, 2015; Yekeen, 2017). In Nigeria, government has introduced the unique Taxpayer's Identification Number (TIN) (effective February, 2008); automated tax system that facilitates tracking of tax positions of taxpayers; epayment system(e-tax) and enforcement scheme (involving special purpose tax officers in collaboration with other security agencies to ensure strict compliance in payment of taxes). All these measures have led to an improvement in tax administration in the country (Asuquo, 2016).

In line with this, Oseni (2015) concluded that there is no hiding place for tax evaders with the use of this modern technology since all potential taxpayers are captured by the system. However, the use of information communication technology (ICT) can be catastrophic if carelessly employed by 
INTERNATIONAL JOURNAL OF ACADEMIC RESEARCH IN ACCOUNTING, FINANCE AND MANAGEMENT SCIENCES

Vol. 11, No. 2, 2021, E-ISSN: 2225-8329 @ 2021 HRMARS

both the taxpayers and tax authorities as scammers and hackers of the internet facilities can utilize the ignorance or lax security of the system.

Technology influences the way we work, play and interact with others and has transformed and impacted the macro environment (Eric and Richard, 2008; Abiola, 2014) Thus, an electronic system of taxation is the application of information and communication technology (ICT) to filing tax returns and 'remitting taxes based on assessment as prescribed by the relevant tax authority. It is not surprising that e-tax system has permeated both, developed and emerging economies, such as Australia, United Kingdom, France, India, China, Singapore, Turkey, Malaysia, Uganda, Rwanda and Nigeria (Ramayah, Ramoo and Amlus, 2008; Muita, 2011). Among the greatest problems facing tax administration in Nigeria are tax evasion, non-tax compliance and collusion of tax officials with taxpayers to circumvent taxpayers (Adegbie and Fakile, 2011; Odia, 2014). However, with e-tax system, revenue collection efficiency is guaranteed, tax compliance would be enhanced, and incidence of tax evasion and avoidance would be greatly reduced (Harrison and Nahashon, 2015; Oseni, 2015).

\section{Electronic Tax System}

Electronic tax system is the process of levying and payment of taxes by the deployment of computer systems and networks. It entails the application of computer techniques in the process of tax assessment, collection and administration generally referred to as e-payments and e-filing. It is an extension of the growing concept of e-commerce and e-governance and involves the exchange of data through information communication technology systems between the tax authorities and tax payers. The objective of this system is to replace cumbersome manual, bureaucratic service systems, with efficient, collaborative, process-driven, and secure online delivery systems" (Arya, 2012).

Electronic tax system was first introduced in three cities in the United State of America (USA) in the year 1986 by the USA Internal Revenue service (IRS). The three cities include: Cincinati, Raleigh-Durham and Phoenix, where five (5) tax preparers filed 25,000 tax returns electronically (Umenweke and Ifediora, 2016). It was during the filing of these 25000 tax returns that the officials of IRS of the USA identified the three (3) major components of electronic tax system to include: electronic tax registration, electronic filing of tax returns and electronic tax payment (Umenweke and Ifediora, 2016). Therefore, a detailed, explanation of the three elements is pertinent to the full understanding of electronic tax system. This is shown by the diagram below: 


\section{Components of Electronic Tax System}

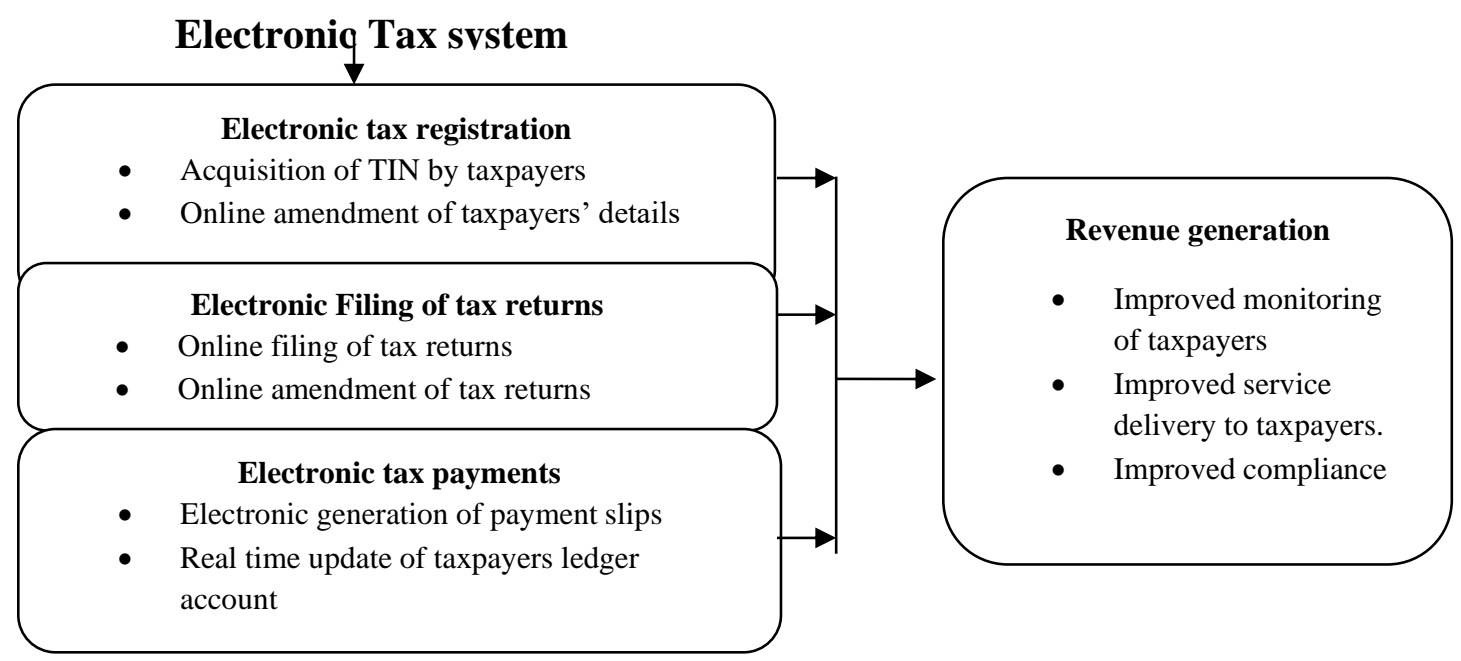

\section{Electronic tax Registration}

As shown in above diagram, electronic tax registration involves acquisition of tax identification number (TIN) by the taxpayers. To obtain an individual taxpayer's identification number, the taxpayer must complete the relevant form that requires documentation of substantiating status and true identity for each individual. This documentation is to be mailed with the form to the address on the form. In line with this, the individual taxpayer identification number is issued after the documents and the information furnished are validated by the relevant tax authority (Umenweke and Ifediora, 2016).

\section{Electronic Filing of tax returns}

This requires taxpayers to have an email address, log on to the website of the tax office and download the relevant form. Pertinent information must be filled such as taxpayer's name, address, identification number, exemption, income, tax credit/deduction, other taxes and payments, amount owed and so on. After filling the tax return form, the taxpayer signs the tax return forms using a selfselected identification number and files it using the tax office. Upon submission of the filled return form, the returned and entire electronic record is transmitted to the tax office for processing where free file is being utilized. An email is sent to the taxpayer as soon as the tax return is received. Subsequently, the tax return is assessed, with the taxpayer's tax calculated within 48hours. Where errors are detected, an error message is sent to the transmitter to correct and re-transmit the return to the tax office (Umenweke \& Ifediora, 2016). For instance, the Ebonyi state board of internal revenue in collaboration with a tax consulting firm-Appmart Integrated Limited have made tax software available to taxpayers and assist them to file returns electronically, and also get assessed electronically.

\section{Electronic tax payment}

Upon being notified of tax due by email, the taxpayers have options through which payments can be made: by debit or credit card through which payment is done through a payment processing company. Payment can also be made by direct debit of the taxpayer's account. This involves where 
INTERNATIONAL JOURNAL OF ACADEMIC RESEARCH IN ACCOUNTING, FINANCE AND MANAGEMENT SCIENCES

Vol. 11, No. 2, 2021, E-ISSN: 2225-8329 ๔ 2021 HRMARS

the tax office automatically withdraws the amount owed from the taxpayer's account from his bank with additional fees.

The technological modernisms are having a weighty influence on the administration of fiscal systems and the way in which taxation is administered. The information and telecommunication sector has proven to be the major driver facilitating internet economy in Nigeria (Abiola, 2014). Of recent, the use of technology to improve the effectiveness of tax administration, expand taxpayer services and enhance tax compliance has come to attract increasing attention in developed and developing countries (Dowe, 2008; Olaoye and Kehinde, 2015). E-tax, according to Amitabh et al, (2008), would assist revenue authority in timely completion and processing of tax returns and issuance of refunds; also, in taking key administrative decisions in tax administration and compliance functions, serving as a source of the most comprehensive, authentic and current financial, business and economic data for policy formulation inside the government. E-tax is a concept that enables taxpayers file their tax returns and make tax payments electronically. In other words, tax administrators and taxpayers communicate online and compliance is enhanced through an online platform created by this system. Electronic tax system hinges on three important concepts: electronic registration, electronic filing (e-filing) and electronic payment (e-payment) (Andarias, 2006). Generally, under an e-filing and e-payment system, returns are filed and payments are made via the internet and the tax administrator sends an electronic confirmation acknowledging receipt of the return and/or payment. In the case of e-payments, the taxpayers also receive a debit confirmation from their financial institution.

Since the advancement of ICT, the operation of tax system has been seriously challenged (Muita, 2011) and one of the ways through which tax authorities have improved interactions with taxpayers is through e-tax system (Wasao, 2014). E-tax system increases the quality and quantity of information available to tax officers, enabling them to complete transactions faster and more accurately. The primary objective of any tax administration anywhere in the world is to maximize revenue collections by improving tax compliance. Before the emergence of electronic tax system, tax administrators have been hindered in the effective and efficient discharge of their primary assignments. As argued by Adegbie and Fakile (2011), tax evasion and tax avoidance have contributed significantly to limiting revenue accruable to the government of Nigeria. Tax administration can better be placed if: tax rules and procedures are simple; tax compliance costs are low; there is easy access of information by taxpayers, and there exists mutual trust between taxpayers and tax authority.

Computer technology must be combined with the political will to enforce tax collection if it is to yield greater revenue. In addition, taxpayer's identification number could be tied to other means of identification such as drivers' licenses or passports or even account opening in the banks. Corrupt-free and efficient administrative machinery with personnel who are adequately trained, well-equipped and motivated would enable Nigeria to make appreciable progress in revenue diversification.

\section{Electronic Tax System}

\section{Transcript Electronic Tax System in Nigeria}

Electronic tax system in Nigeria is still evolving and relatively new. Its introduction in Nigeria was heralded by the reports of the visiting teams of the International Monetary Fund (IMF) Fiscal Affairs Division in 2004, 2005 and 2006 which recommended the implementation of an Integrated Tax 
INTERNATIONAL JOURNAL OF ACADEMIC RESEARCH IN ACCOUNTING, FINANCE AND

MANAGEMENT SCIENCES

Vol. 11, No. 2, 2021, E-ISSN: 2225-8329 @ 2021 HRMARS

Administration System (ITAS). The FIRS was given approval by the Federal Executive Council to procure, install and implement the ITAS in December 2010 (Usman U.Y 2013). The ITAS is aimed at automating and re-engineering the FIRS tax administration process as well as the procurement, installation and deployment of the Standard Integrated Government Tax Administration (SIGTAS) and hardware infrastructure (Usman U. Y 2013). The F.I.R.S in 2015, partnered with the Nigerian Interbank Settlement System (NIBBS) to provide for the electronic payment of taxes in Nigeria. This is an automation of all tax processes from tax registration, assessment and filing of returns to payment of taxes. The objective was to adopt an electronic system to make it easier to pay taxes online in major cities across Nigeria (Abdulrazaq A. O, 2018). The F.I.R.S restructured the electronic tax system in June 2017 to operate nationwide by introducing six new electronic tax services (e-services), the available e-services are according to Deloilte Nigeria Blog (2017) are:

E-registration: for registration of new tax payers with F.I.R.S for the various taxes. With this service, taxpayers do not need to visit any tax office to register for tax purposes they just need to visit the F.I.R.S website and register.

E-stamp duty: For payment of stamp duties on qualifying documents. This innovation will increase the ease of doing businesses in Nigeria. Physical stamping in the past was required to perform transactions that require stamping. With e-stamping, stamping can be done anywhere at any time online, one area in which this innovation is very useful is when a new company is being incorporated at the corporate Affairs Commission (CAC). From the CAC registration site, you can migrate to the FIRS e-service site and pay your stamp duties.

E-tax payment: For payment of all Federal Government taxes and levies through any of the following platforms. Nigeria Inter-Bank Settlement (NIBSS), Remita and Interswitch. This brings payment of taxes to your doorstep as you can pay your taxes from the comfort of your home.

E-receipt: For receiving and verifying e-receipts generated for taxes paid through the new e-tax payment with this you receive instant notification acknowledging your payment of tax.

E-Filling: This enables tax payers to file their tax returns through the FIRS ITAS online. This is one of the most innovative aspects of the e-tax services. It is a mandatory requirement of the law to file tax returns. This platform obviates the need to visit any tax office to file tax returns as you can upload relevant documents and file your tax returns electronically.

Electronic tax clearance certificates(e-tcc): This platform enables taxpayers to apply for, receive and verify the authenticity of their e-tcc. Obtaining tax clearance certificate under the manual tax administration process is cumbersome. With e-Tcc, a certificate is automatically sent to the email addresses of tax payers and its authenticity can be confirmed on the e-service website. These eservice initiatives combine innovation and technology in tax administration to make the F.I.R.S Services convenient, easy and available everywhere and at all times (vanguard news paper, 2017). There is no comprehensive legislative framework for the operation of the electronic tax system in Nigeria, however, the National tax policy (NTP) encourages, the use of technology in the administration of tax laws. The policy provides. 
INTERNATIONAL JOURNAL OF ACADEMIC RESEARCH IN ACCOUNTING, FINANCE AND MANAGEMENT SCIENCES

Vol. 11, No. 2, 2021, E-ISSN: 2225-8329 @ 2021 HRMARS

"Federal and State tax authorities should respond promptly to the changing business environment as it affects tax administration and develop a workable framework to meet the taxpayer demands in this respect" (NTP, 2018).

\section{Challenges of Electronic Tax system in Nigeria}

The Electronic tax system in Nigeria is confronted with several challenges which include a low computer literacy level and the high cost of setting up on electronic tax system (Umenwekeand Ifediora, 2016). Also its effectiveness is highly dependent on the availability of an efficient internet service. Several places in Nigeria at the moment do not enjoy an effective internet service, especially in rural areas. Although there is a steady rise in the number of people with access to the internet and improved connectivity, a lot still needs to be done as the percentage of people without access to the internet in Nigeria is approximately $50 \%$ of its population, considering that its estimated population is put at about 198 million in 2018 (NPC, 2018). This challenge is further compounded by the unreliable electricity power supply in Nigeria. Another challenge of the electronic tax system in Nigeria is that only the FIRS, which is the Federal Tax Authority, has fully automated its processes. At the state level, many tax authorities are still using manual tax processes or combining the manual and electronic tax system. The situation inhibits effective collaboration between tax authorities at the Federal and State levels to prevent double taxation. There is urgent need for the state revenue authorities to automate their processes to provide the necessary synergy with the F.I.R.S. This will contribute positively to the rating of Nigeria on the ease of doing business index as investors will find it easy to fulfill their tax obligations to the federal and state governments through convenient and transparent electronic tax payment platforms and also assist tax authorities to easily share information on a tax payer and build up a comprehensive tax history of taxpayers. The greatest threat to electronic tax system in Nigeria is the activities of cyber criminals, who try to compromise the integrity of the tax revenue service portals. Electronic tax fraud (cyber tax crime) is a major challenge to the development and sustainability of electronic tax systems.

\section{Tax Compliance in Nigerian Emerging Economy}

Tax compliance in its most simple form is usually viewed to mean the full payment of all taxes due (Braithwaite, 2009) which includes timely filling and reporting of required tax information, the correct self-assessment of taxes owed, and the timely payment of those taxes without enforcement action (Andreoni, Erard and Feinstein, 1998; Jones, 2009). From this definition results three dimensions of tax compliance: filing, reporting and payment compliance. A compliant taxpayer would submit the correct forms to the revenue authority; render accurate return and pay tax liability in a timely manner. A taxpayer would be declared non-compliant if the three dimensions are not properly accomplished (Wasao, 2014).

Voluntary compliance is made possible by the trust and cooperation ensuing between tax authority and taxpayer and it is the willingness of the taxpayer to comply with tax authority's directives and regulations. This is aided by such factors as the efficiency and efficacy of government services, the perceived level of fraud and corruption in the government and whether government is serious in combating fraud and corruption (Fagbemi and Abogun, 2010; Wang, 2010). The presence of tax non-compliance results from: the growing dissatisfaction of the fairness of tax system (Chau and Leung, 2009); mistakes done by a taxpayer while filling his 
INTERNATIONAL JOURNAL OF ACADEMIC RESEARCH IN ACCOUNTING, FINANCE AND MANAGEMENT SCIENCES

Vol. 11, No. 2, 2021, E-ISSN: 2225-8329 ๑ 2021 HRMARS

tax form or intentional omission (Fagbemi and Abogun, 2010); the increase of administrative cost of tax collection (Tanko, Okpara and Ajape, 2013).

Therefore, boosting tax compliance level has remained a source of concern to policy makers, tax administrators and society in general (Wasao, 2014). This is mainly because tax compliance affects revenue collection and the ability of the government to achieve its fiscal and social goals (Tan and Sawyer, 2003). In order to achieve higher voluntary compliance and bridge tax gap, researchers have advocated for tax education and review of tax laws to include stringent penalty for tax defaulters (Tankoet al., 2013) and introduction of electronic tax system (Khadijah, 2013).

The primary objective of a modern tax system is generation of revenue to help the government to finance increasing public sector expenditure (Afuberoh and Okoye, 2014). According to Aguolu (2004), taxation constitutes the most important source of governmental revenues, from the point of view of certainty and consistency of taxation. This implies that owing to the inherent power of government to impose taxes, the government is assured of its tax revenue no matter the circumstances. Olotu (2012) mentioned that taxation is already showing signs of transformation in many states of the federation of Nigeria. She pointed that states like Imo, Edo, Rivers and Lagos have seen their tax revenues tripled and quadrupled in recent times and this has enabled the implementation of numerous life and community transforming projects and to finance critical infrastructural projects.

\section{The Concept of Internally Generated Revenue in emerging economy}

These are revenues that accrue to the state government from its internal activities without recourse to external sources (Tunji, Olajide and Olubukunola, 2014). To avoid disappointment or embarrassment from non-remittance of allocation form federal government, state government needs this as often time, allocation from federal government is being delayed and government at the state level cannot endlessly wait for the allocation before it can carry out its responsibilities to the citizenry. Internally Generated Revenue (IGR) also denotes the revenue that the federal, state and local governments generate within their respective areas of jurisdiction (Abiola \& Ehigigiamusoe, 2014). IGR for State government has also been described as revenues that are derived within state from various sources such as taxes (pay as you earn, direct assessment, capital gain taxes, etc) and motor vehicle license, among others (Adenugba \& Chike, 2013). According to Asimiyu and Kizito (2014), economic development and sustainability of states in Nigeria depend on the ability of such states to generate revenue internally to supplement the revenue allocation from federation account. Unfortunately, the rich source of IGR in the Nigerian regions providing unlimited economic development has been sacrificed at the dwindling 'altar of oil'. The undue dependence on statutory allocations has become a major constraint why most Nigerian states cannot perform their basic functions (Balogun, 2015). Nnanseh and Akpan (2013) believe that IGR is capable of providing adequate basic infrastructures in a state citing Akwalbom State as a case study where IGR contributed so much in the provision of water, roads and electricity. Oseni (2013) posits that IGR is mainly used to offset the high cost of governance by the second and third tiers of government. Therefore, mismanagement of IGR by political leaders remains a serious challenge as it affects the economic development of such state. 
INTERNATIONAL JOURNAL OF ACADEMIC RESEARCH IN ACCOUNTING, FINANCE AND MANAGEMENT SCIENCES

Vol. 11, No. 2, 2021, E-ISSN: $2225-8329$ @ 2021 HRMARS

\section{Empirical Review}

Ofurum, Amaefule, Okonya and Henry (2018), empirically examined the impact of E-taxation on Nigeria's revenue and economic growth: A pre-post analysis. The study aimed at determining how the implementation of E-taxation in 2015 has affected tax revenue, federally collected revenue and tax-to-GDP ratio. Data were sourced through secondary means from Federal Inland Revenue service and CBN statistical and economic reports on quarterly basis from the second quarter of 2013 to fourth quarter 2016. Analysis of data was done through the use of paired sample t-test and simple regression. The findings of the analysis revealed that the implementation of electronic taxation has not improved tax revenue, federally collected revenue and tax-to-GDP ratio in Nigeria. It was recommended amongst others that federal government through the federal Inland Revenue Services should conduct more enlightenment seminars in all 36 states in the country to increase the knowledge on the use of all electronic services on their platform.

Obert, Rodgers, Tendai and Desderio (2018), evaluated the effect of e-tax filing on tax compliance in Zimbabwe. The objective of the study was to determine how the e-tax filing has influenced tax compliance by clients in Harave, Zimbabwe. Data were collected through the aid of structured questionnaires. Analysis of data was done using multiple regression with the aid of SPSS version 20.0. The results of the analysis showed that: electronic filing actually influenced tax compliance; that there was a positive attitude by clients towards electronic filing and finally, that electronic filing has also significantly increased the case of doing business.

Olurankinse and Oladeji (2018), examined self-assessment, electronic taxation payment systems and revenue generation in Nigeria. The study population comprised of 30 companies quoted in Nigeria stock exchange. Pearson's product moment correlation coefficient statistical tool and regression analysis were used to test the hypothesis by the application of SPSS Version 20.0. Results of the analysis indicated a position and significant relationship between self-assessment and e-taxation payments systems and revenue generation. Also, Omodero, Ekwe and Ihendinihu (2018), investigated the impact of internally generated revenue (IRG) on economic development in Nigeria. The objective of the study was to examine the impact of internally generated revenue on the economic development of Nigeria. Time series data that was used, covering the period of 1981 to 2016, and were gathered from the Central Bank of Nigeria (CBN) statistical Bulletin. The statistical tool used for the data analysis was the multiple regression and t-test for test of hypotheses. The findings of the study revealed that total internally generated revenue, state internally generated revenue and local internally generate revenue have robust and significant positive impact on real gross domestic product; while federal internally generated revenue indicated positive and significant influence on real gross domestic product. The study recommended that government officials with corruption history should not be allowed to continue to handle responsibilities rather, people with outstanding integrity should be given opportunity to occupy government positions that are sensitive. Madegwa, Makokha and Namusonge (2018), investigated the effect of automation of revenue collection on the performance of country government in Kenya. The objective of the study was to determine the effect of communication and the performance of Trans Nzioa country government in Kenya. The study used a semi structured self-administered questionnaires to collect data from the respondents. Data was analyzed using descriptive statistic with the application of SPSS. The result of the analysis showed that online process of automation of revenue collection process influence performance in Trans Nzioa country government office to a great extent. From the findings, the study 
INTERNATIONAL JOURNAL OF ACADEMIC RESEARCH IN ACCOUNTING, FINANCE AND MANAGEMENT SCIENCES

Vol. 11, No. 2, 2021, E-ISSN: 2225-8329 ๔ 2021 HRMARS

recommended that automation of the revenue management process should be improved to enhance efficiency in the revenue collection process.

Ajape, Afara and Uthman (2017), empirically investigated the influence of E-tax system on Tax administration and Tax revenue generation in Lagos state Internal Revenue Service. The objective of the study was to determine the influence of an electronic system of taxation on tax administration efficiency and tax revenue generation in Lagos state Survey research design was adopted using a structured five point Likert scale questionnaire to obtain data. Data gathered were analyzed using descriptive statistics, while hypotheses were tested using the multivariate analysis of variance (MANOVA) with the aid of SPSS. Major findings of the study revealed that respondents do not differ that e-tax system has enhanced revenue generating potentials of Lagos state. The study recommended that relevant tax authority should formulate and implement policies that would promote the sustainability of positive effects of the e-tax system and to train tax official on how to harness the benefits of administering taxes electronically.

Olatunji and Ayodele (2017), examined the impact of information technology on tax administration in South West, Nigeria. The study specifically investigated the effect of information technology on tax implementation and tax planning. Data was collected through the means of structured questionnaires, while multiple regression and Pearson product moment correlation were used to analyze the data. Findings from the analysis revealed that information technology enhance the level of tax productivity and administration. The study recommend that respective agencies (Federal, State and Local Governments) responsible for tax collection should carry out one on one awareness in the form of seminars and sensitization of the process and suitability of information technology on tax administration.

Bett and Yudah (2017), examined the contribution of i-tax system as a strategy for Revenue collection at Kenya Revenue Authority. The objective of the study was to ascertain the contribution of integrated tax system as a strategy for revenue collection in Kenya revenue authority. A five-point Likert Scale structured questionnaire was used to collect primary data. Both descriptive and inferential statistics were used to analyze the data. Statistical significance of relationship among selected variables was determined using multiple regression analysis. The study established that online taxpayer registration, online tax return processing, online compliance and monitoring activities; and electronic tax payment have a significant contribution on revenue collection at Kenya revenue authority. The study recommended that Kenya revenue authority management should focus on taxpayer facilitation through a robust system of customer relationships management, efficient complaints resolution and ensuring that more resources are invested in user friendly online tax systems in order to realize long term benefits.

Monica, Makokha and Namusonge (2017), investigated the effect of electronic tax system on tax collection efficiency in domestic taxes department of Kenya revenue authority (KRA). The objectives of the study were to find out the effect of electronic tax filing on revenue collection efficiency; examine the effect of staff competency on revenue collection efficiency and to ascertain the level of taxpayers' knowledge in operating electronic tax system in Kenya. The main data collection tools were questionnaires administered to the employees of KRA and taxpayers. Descriptive and inferential statistics were employed as data analysis technique. Findings from the study revealed that most tax payers strongly agreed that they were able to fully access and operate the tax system. Secondly, Employees competence was a significant predicator of the tax collection efficiency while taxpayers seeking clarifications on tax issues online is minimal. 
INTERNATIONAL JOURNAL OF ACADEMIC RESEARCH IN ACCOUNTING, FINANCE AND MANAGEMENT SCIENCES

Vol. 11, No. 2, 2021, E-ISSN: 2225-8329 @ 2021 HRMARS

Owino, Otieno and Odoyo (2017), empirically examined the influence of information and communication technology (ICT) on revenue collection in county government in Kenya. The objectives of the study were to determine the influence of ICT system for single business permits on revenue collection; evaluate the influence of ICT system for land rates on revenue collection; establish the influence of ICT system for bus park on revenue collection in Migori and Homa Bay county governments in Kenya. Primary data were collected with the use of questionnaires, and analyzed using descriptive and regression techniques. The finding showed that a strong and almost a perfect association existed between ICT systems adopted in county governments and the revenue collection; the application of ICT systems explain up to $91.9 \%$ variation in revenue collection efficiency in county governments.

Further findings revealed that the application of those systems improve revenue collection efficiency in the county governments.

Metin, Ali and Metehan (2017), explored the effect of e-taxation system on tax revenues and costs in Turkey. The study aims to investigate the effect of electronic taxation system on tax revenues and tax collection cost in Turkey. Data were sourced through secondary means in the republic of Turkey. The data were examined in two groups, that is pre-electronic tax period of $1993-2004$ and postelectronic tax period of 2005 - 2016. Mann-Whitney U-test was used to analyze the data. The result of the analysis showed that the organization of the electronic tax system positively affected the tax revenues and reduced the cost per tax.

Obara and Nangih (2017), empirically investigated tax compliance barriers and internally generated revenue in Nigeria: A study of small and medium enterprises in portharcourt. The objective of the study was to examine the effect of taxation barriers on government's revenue generation in Nigeria. Primary data were collected using structured questionnaires, while formulated hypotheses were analyzed using simple regression analysis with the aid of SPSS software. The result of the study showed that problems of reliable tax database and the prevalence of cash transaction impede government's revenue generation in Nigeria. The study recommended that effective tax automation, regular education of taxpayers on the benefits of paying tax, training of revenue staff and provision of adequate logistics for efficient tax administration are some of the measures to ensure improved revenue generation in Nigeria.

Fave and Dabari (2017), studied the empirical analysis of tax revenue collection by the federal government in Nigeria. The main objective of the study was to analyze tax revenue collection by the federal government in Nigeria. Secondary data was obtained from the Federal Inland Revenue Service (FIRS) in respect of the total tax revenue collected from the oil and non-oil taxes for the period of 2011 - 2015. The data was analyzed using multiple regression with the aid of SPSS version 20.0. Findings from the study revealed that capital gains tax, stamp duty, education tax and petroleum profit tax are positively significant at $1 \%, 5 \%$ and $10 \%$ respectively while company income tax and value added tax are not significant. Moreover, company income tax has more total collected revenue than all the remaining variables. The study recommended that government should enhance the collection of tax revenue processes and ensure that any deviation from compliance with the laid down rules and regulations are severely dealt with and punished accordingly.

Ndayisenga and Shukla (2016), evaluated the effect of electronic tax management system on tax collection efficiency in Rwanda. The research aimed to examine the effect of electronic tax management system on revenue collection by Rwanda Revenue Authority. Data were gathered through the means of structured questionnaires. Pearson's correlation analysis and regression 
INTERNATIONAL JOURNAL OF ACADEMIC RESEARCH IN ACCOUNTING, FINANCE AND MANAGEMENT SCIENCES

Vol. 11, No. 2, 2021, E-ISSN: 2225-8329 @ 2021 HRMARS

analysis were used to analyzed and present the results of the study. In the findings of the study, it was established that electronic tax management system contributed to timely tax payment and reduced operational costs. The study therefore concluded that electronic tax management system contributed positively to revenue collection in Rwanda.

Maisiba and Atambo (2016), investigated the effect of electronic tax system on the revenue collection efficiency of Kenya Revenue Authority (KRA). The study was set to determine the effect of electronic tax system on revenue collection efficiency in Kenya Revenue Authority. The main data collection tools were questionnaires administered to the 102 targeted respondents; that included employees of KRA and taxpayers collected data from the field were analyzed using descriptive and inferential statistics. The key findings were that most respondents agreed that KRA has good electronic tax payment system and that for the KRA officials; most of them are conversant with its use and are trained. However, most taxpayers indicated difficulty in using the system and blamed lack of computer knowledge, poor internet and unstable power supply as major reasons.

Gwaro, Maina and Kwasira (2016), evaluated the influence of online tax filing on tax compliance among small and medium enterprises in Nakuru town in Kenya. The study aims to asses the level of awareness regarding online filing of tax returns in the context of the small and medium enterprises in Nkum in Kenya. Primary data was collected using structured questionnaires while its analysis was done using descriptive statistics. Multiple linear regression was used to determine the relationship between the research variables. The study found that amongst the independent variables, only the computer literacy had significant effect on the influence of tax compliance levels amongst small and medium enterprise in Nkuru.

Asaolu, Dopemu and Unam (2015), empirically investigated the impact of tax reforms on revenue generation in Lagos State. The study assessed the impact of tax reforms on revenue generation in Lagos State of Nigeria using time series quarterly data between the period of 1999 and 2012, obtained from the records of taxpayer statistics and the revenue status report of Lagos State Internal Revenue Service (LIRS). Data collected were analyzed using ordinary least square regression techniques (OLS). The study showed that Lagos State captured more people into the tax net as there was a continuous increase in taxpayers' cumulative growth (more than 20\% each year); and also found that the primary source of revenue generation in Lagos State was the internally generated revenue (IGR) in which tax revenue constituted about $80 \%$. The result also revealed that, on trend, between 1999 and 2005, there was no noticeable increase in revenue generated from tax; but from 2006 , there was a sharp, steady and noticeable increase in the revenue generated. The study further revealed that there was a long run relationship between the tax reforms and revenue generated in Lagos State.

Muturiand Kiarie(2015), examined the effect of online tax system on tax compliance among taxpayers in Meru, county, Kenya. The objective of the study is to establish the effect of online tax system on tax compliance among small taxpayers in county tax district. Multiple regression and descriptive statistics were used in data analysis. The findings of the study were that online tax system does affect tax compliance level among small taxpayers in Merucounty. The study recommended that further study should be done to establish other factors that affect tax compliance among small taxpayers. Ngigi (2015), empirically investigated the effect of integrated tax management system on tax compliance by small and medium enterprises in the central business district in Nairobi County. The objective of the study was to ascertain the effect of integrated tax management system on tax compliance by small and medium enterprises in the central business district of Nairobi Kenya. 
INTERNATIONAL JOURNAL OF ACADEMIC RESEARCH IN ACCOUNTING, FINANCE AND MANAGEMENT SCIENCES

Vol. 11, No. 2, 2021, E-ISSN: 2225-8329 ๑ 2021 HRMARS

Collection of primary data was done through the use of questionnaires that were dropped to the sampled respondents and picked after two days. The data collected was analyzed using descriptive and inferential statistics with the aid of SPSS; while multiple linear regression was used to establish the relationship between the independent and dependent variables. The study established that the amount of fines and penalties paid and tax consulting/filing expenses have a positive and significant relationship with tax compliance. The study recommended that KRA should increase the fines and introduce stringent penalties for non-compliance since this would encourage small and medium enterprise owners to comply with taxes.

Okoye and Ezejiofor, (2014), investigated the impact of electronic taxation on revenue generation in Enugu, Nigeria; Data were collected using both primary and secondary sources, using frequency counts, mean score. The ordinary least square method was adopted using the multiple regression analysis and panel data regression method to test the fixed and random effects and test for level of significant at $1 \%$. The finding was that electronic taxation can enhance internally generated revenue and reduce the issue of tax evasion in Enugu state. Another finding is that electronic taxation can prevent corrupt practices of tax officials. It also recommended that the Government should support the establishment of electronic tax administration so as to start ripping the benefit of high rate of compliance among taxpayers and electronic tax system should be implemented to reduce the diversion of government funds to private pockets.

Afuberoh and Okoye (2014), evaluated the impact of taxation on revenue generation in the federal capital territory and selected states in Nigeria. The study was aimed at finding out the impact of taxation on revenue generation in Nigeria. The questionnaire which was used to obtain the data was designed in a closed-ended form of strongly agreed, agreed, strongly disagreed and disagreed responses. The testing of the hypotheses of the study was done using regression analysis with the aid of SPSS version 17.0. The research discovered among others that, taxation has a significant contribution to revenue generation and taxation has a significant contribution on Gross Domestic product (GDP). The research recommended that well-equipped data base (WEDB) of all tax-payers should be established by the federal, state and local governments with the aim of identifying all possible sources of income of tax-payers for tax purposes; and that tax collection processes must be free from corruption.

Wasao (2014), examined the effect of online tax system on tax compliance among small taxpayers in east of Nairobi tax district. The objective of the study was to establish the effect of online filing system on tax compliance among small taxpayers in East of Nairobi tax district. Data was collected using structured questionnaires, which covered all the variables of the study of 160 sampled taxpayers based in East of Nairobi tax district. Data was analyzed using descriptive statistics while regression analysis was also done to determine the effect of the independent variable on the dependent variable. The findings of the study were that online system do affect small compliance level among small taxpayers in East of Nairobi as far as registration, filing and payment were concerned. From the regression analysis, it was revealed that holding online tax registration, filing and payment to a constant zero, tax compliance would stand at 3.663. A unit increase in online tax registration would lead to increase in tax compliance among small taxpayers in east of Nairobi by factor of 0.051 and a unit increase in tax filing would lead to an increase in tax compliance by factor of 0.161 while a unit increase of online tax payment would result to increase in tax compliance by factor of 0.086 .

Eneojo and Gabriel (2014), investigated taxation and revenue generation in some selected states in Nigeria. The study is aimed at highlighting the concept and nature of taxation and its effect on 
INTERNATIONAL JOURNAL OF ACADEMIC RESEARCH IN ACCOUNTING, FINANCE AND MANAGEMENT SCIENCES

Vol. 11, No. 2, 2021, E-ISSN: 2225-8329 ๔ 2021 HRMARS

revenue generation and gross domestic product. The researcher adopted both primary and secondary sources of data to present and analyze the information for the study. The testing of hypotheses were done using regression analysis via SPSS version 17.0. The researcher discovered that taxation has a significant contribution on gross domestic product (GDP); while tax evasion and avoidance have a significant effect on revenue generation in Nigeria. The study recommended that well equipped database of taxpayers should be established by the federal, state and local governments with the aim of identifying all possible sources of income of taxpayers for tax purposes, the tax collection must be free from corruption and stringent penalties should be meted out on people who evade and avoid tax payments.

Mararia (2014), examined the effect of integrated tax management system on tax compliance by small and medium sized enterprises in Nairobi central business district. The objective of the study was to determine the effect of integrated tax management system (ITMS) of the year, 2007 on tax compliance by medium and small taxpayers. The target population comprised of 200 taxpayers; while a total sample size of 100 was selected. Data was collected using self administered questionnaires and an interview guide. Analysis of the collected data was done using descriptive statistics and multiple regression with the aid of SPSS version 17.0. The study findings provided direct evidence that adoption of integrated tax management system is a contributory factor in tax compliance. From the study, findings revealed that there was enough proof to conclude that adoption of the integrated tax management system is associated with high levels of tax compliance. The study also found that, to enhance tax compliance, governments should enhance adoption of electronic filing systems such as integrated tax management system, reduce tax compliance costs and enhance tax fines and penalties as well as tax knowledge and education.

Alake and Olatunji (2012), examined the impact of electronic taxation on tax evasion and a voidance in Nigerian Banks. The objective of the study was to investigate the impact of electronic taxation on tax evasion and avoidance in Nigeria. Well-structured questionnaires were administered to the targeted respondents and were analyzed using descriptive statistics. The result of the analysis showed that adoption of electronic taxation in tax administration in Nigeria significantly reduces the incidence of tax evasion and avoidance in Nigeria.

Ebimobowei (2012), examined the impact of tax reforms on the economic growth of Nigeria from. The objective of the study is to prove that the Nigerian tax system needs to be reformed in order to achieve long term economic growth and development.

Relevant secondary data were collected from the Central Bank of Nigeria (CBN) Statistical Bulletin, Federal Inland Revenue Service, Office of the federation and other relevant government agencies. The data were analyzed using descriptive statistics and econometric models such as while test, Ramsey reset test and Breusch Godfrey test. The results from the various tests showed that reforms on the tax system are positively and significantly related to economic growth. On the basis of findings, the study concluded that tax reforms improve the revenue generating machinery of government to undertake socially desirable expenditure that will translate to economic growth in real output and per capital basis. The study recommended that sustainable economic growth cannot be attained with tax reform processes except obsolete tax laws and rates are reviewed in line with macro-economic objectives, corrupt free and efficient tax administrative machinery with personnel's and accountability and transparency of government officials in the management of tax revenue.

Leyira, Chukwuma Asia, (2012), evaluated tax system in Nigeria-Challenges and the way Forward. The study analyzed the challenging issues affecting the tax system in Nigeria. It is characterized by lack of 
INTERNATIONAL JOURNAL OF ACADEMIC RESEARCH IN ACCOUNTING, FINANCE AND MANAGEMENT SCIENCES

Vol. 11, No. 2, 2021, E-ISSN: 2225-8329 ๔ 2021 HRMARS

statistical data, poor tax administration, and inability to prioritize tax effort, multiplicity of taxes and increase in underground economy. It also proffer challenges so as to engender an efficient and effective tax regime in Nigeria. The study concludes that the foregoing offer a theoretical framework for improving some salient issue in Nigeria's tax system, suggesting challenges and possible remedies. As must be clear by now, tax is a complex phenomenon that affects both the government and the citizenry and they consider autonomy, efficient and effective tax administration, use of computer technology, strengthening auditing, tax rates and use of tax money and public enlightening as raised as crucial to overcoming the challenges inherent in the entire tax system with a view to enabling Nigeria derive the potential of fiscal policy re-engineering.

\section{Theoretical Review}

This study adopts eclectic theoretical approach. The first theoretical framework underpinning this study is rooted in expediency theory of taxation. The expediency theory of taxation was propounded by Buehler in 1936. The theory stated that every tax revenue collection system must pass the test of practicability, which must be the only consideration when government is choosing a revenue collection system. The assumption of this theory is that the economic and social objectives of the government should be treated as irrelevant, since it is useless to have a tax which cannot be levied and collected effectively. This theory is relevant to the study in that electronic tax system is expected by state board of internal revenue to enhance revenue collection by creating an enabling technological environment that facilitates efficient assessment and revenue collection process. The expediency theory is therefore linked to this study since it seeks to explain the influence of administrative set up, such as efficient electronic tax payment system, in revenue collection by the board of internal revenue.

\section{Technology Acceptance Model}

The second theory is Technology Acceptance Model (TAM). This theory was developed by Fred Davis in 1986. The Technology Acceptance Model is an information systems theory that models how users come to accept and use a technology. The theory is based on the assumption that the acceptability of an information system is determined by two main factors, being Perceived Usefulness (PU) and Perceived Ease Of Use (PEOU). Perceived Usefulness is the degree to which a person believes that using a particular system would enhance his or her job performance. Perceived Ease of Use (PEOU) is the degree to which a person believes that using a particular system would be free from effort. This theory is relevant to this study in the sense that the Technology Acceptance Model provides the bases for the adoption and implementation of the electronic tax system by the State Board of Internal Revenue Service based on the assumption of its perceived usefulness on both the tax payers and tax of officials. The primary objective of the e-tax system is to solve the challenges of the traditional tax system which makes the State Board Internal Revenue Service the forerunner in the acceptance of the e-tax technology mainly because it has a direct positive effect on their job performance in terms of efficiency, timeliness, accuracy and reliability. As for the tax payers, the perceived usefulness of the e-tax system will be the general ease of paying taxes in terms of accuracy, simplicity, convenience and trust in the tax system which will in turn bring about voluntary compliance, hence solving one of the major problems of taxation in the state. The assumption of perceived ease of use on the other hand is however, a hindrance to both tax payers and tax officials who may feel they do not have what 
INTERNATIONAL JOURNAL OF ACADEMIC RESEARCH IN ACCOUNTING, FINANCE AND

MANAGEMENT SCIENCES

Vol. 11, No. 2, 2021, E-ISSN: 2225-8329 @ 2021 HRMARS

it takes to actually use the technology without much effort. This is mainly due to lack of technological exposure which poses a major threat to the use of e-tax system in emerging economy.

\section{Methodology of Research \\ Research Setting}

The research setting of this study is Ebonyi State, located in the South Eastern part of Nigeria. The survey is conducted in the Ebonyi State Board of internal revenue; the body solely in charge of revenue collections in the state via different tax system. The researchers adopted cross-sectional survey design, since the study involves people's perceptions, attitude and orientation. No doubt, cross-sectional survey enables researcher to collect information about a population at a point in time. Population of the study is 123; comprising all the senior staff of the Board who are deeply involved in electronic tax system administration in the state. Meanwhile, the choice of senior staff were based on the researchers' belief that these categories of staff have acquired reasonable experiences in tax administration and have the ability to provide valid responses to the questionnaires administered. $A$ sample size of 94 was obtained using Taro Yamanies formula. The questioner was structured in a 5point likert scale, validated and tested for high reliability and internal consistence. Random sampling technique was adopted to select the respondents who were administered with the questionnaires. This implies that every senior staff of the Board had equal chances of getting questionnaires from the researchers. Out of the 94 questionnaires distributed, only 87 were returned and used for analysis of this study. The research instrument contains 15 metric questions on electronic tax system bordering on the construct of electronic tax system in the state name-electronic tax registration, electronic filing of tax returns, and electronic payment, and 5 metric questions on internally generated revenue variable. The respondents were required to indicate the level of agreement on a 5-point likert scale (where 5 = strongly agree; 4 = agree; 3 = undecided; 2 = disagree; and 1 = strongly disagree)

\section{Research Hypotheses}

The following hypotheses were developed by the researchers using the three major components of electronic tax system from the literature to guide the study in accomplishing its major objectives.

$\mathrm{H}_{1}$ : Electronic tax registration significantly affect internally revenue generation in Nigerian Emerging economy

$\mathrm{H}_{2}$ : Electronic filing of tax returns significantly affect internally revenue generation in Nigerian Emerging economy

$\mathrm{H}_{3}$ : Electronic tax payment significantly affect internally revenue generation in Nigerian Emerging economy

\section{Reliability and Consistency Analysis}

The purpose of reliability assessment in survey research that involves use of questionnaire instrument is to ensure that the research instrument proves consistency beyond reasonable doubt in repeated applications. In this study, the reliability assessment was done to achieve this purpose. Accordingly, the minimum benchmark that must be achieved to establish reliability of research instrument is 50\%value of Cronbach's alpha ( $\alpha \geq 50 \%)$. The results of our reliability test indicate an excellent reliability outcome. From our results, the overall Cronbach alpha standard values for the four variables range from between $87 \%$ (highest value) and $51 \%$ (lowest value) at both extremes. 
INTERNATIONAL JOURNAL OF ACADEMIC RESEARCH IN ACCOUNTING, FINANCE AND MANAGEMENT SCIENCES

Vol. 11, No. 2, 2021, E-ISSN: 2225-8329 @ 2021 HRMARS

The individual reflective indicators of the questionnaire item also showed high level of reliability with adequate scale mean with the provision for deletion of item. The reliability of the individual questionnaire item was tested for the purpose of internal consistency. The result shows a reliability output that indicate high level of consistency between the overall Cronbach's Alpha results for the four major constructs or variables and the individual reflective construct or the questionnaire items. The values individual reflective construct ranges from $90 \%$ to $50 \%$ except for two items in IGR where $36 \%$ and $48 \%$ was recorded and one item in Electronic tax filing which recorded $47 \%$. Though there were provisions for deletion of item in the scale, no item was deleted as the researchers deliberately ignored it because of the good result already achieved in the majority of the variables and the reflective constructs. Meanwhile, the summary of the reliability test is presented in table 2 . For validity measurement, the researcher applied content validity to validate the instrument because most of our scale was adopted from prior studies with minor modifications.

Table 2: Reliability and Internal Consistency Analysis

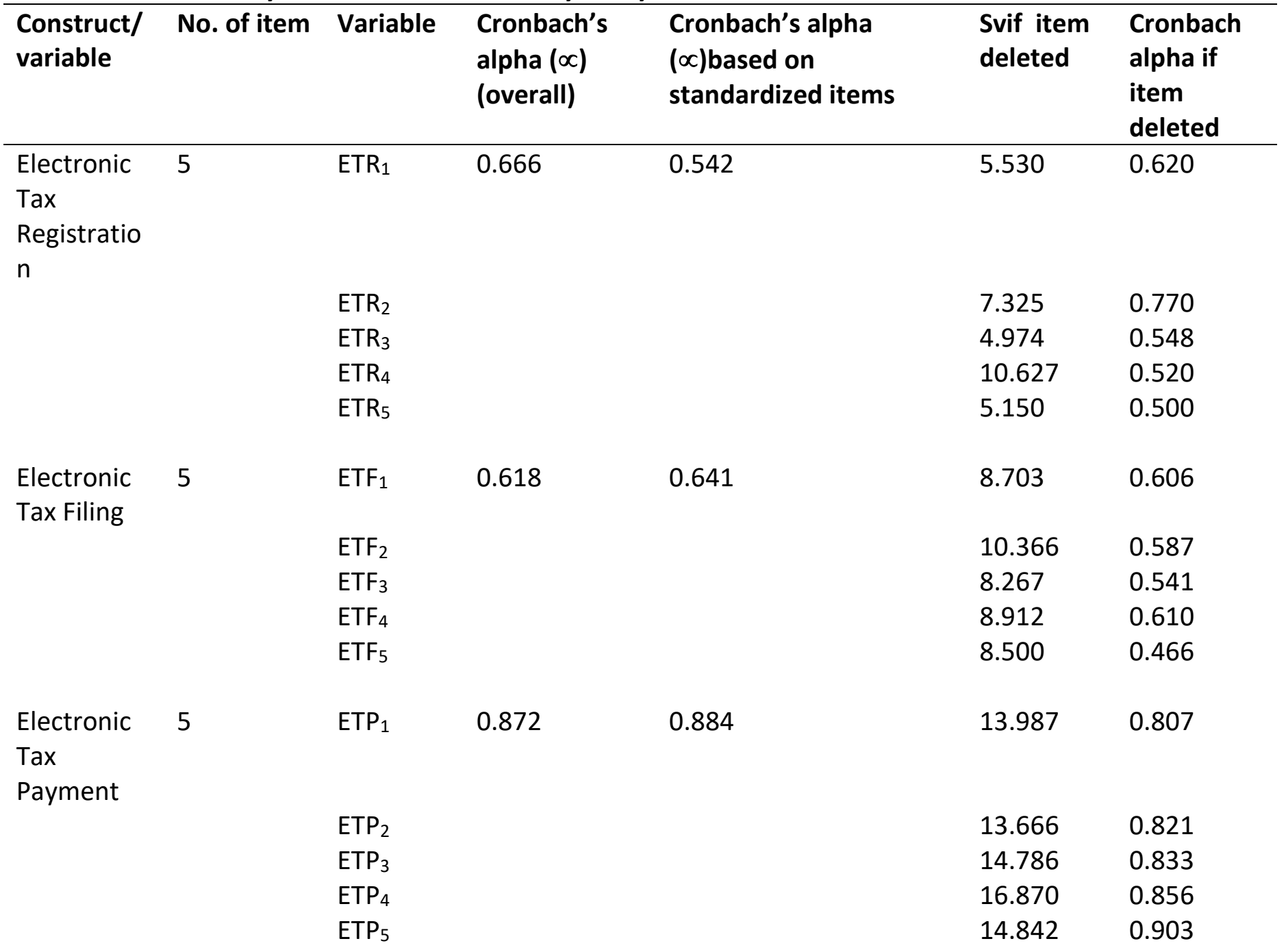


INTERNATIONAL JOURNAL OF ACADEMIC RESEARCH IN ACCOUNTING, FINANCE AND

MANAGEMENT SCIENCES

Vol. 11, No. 2, 2021, E-ISSN: 2225-8329 @ 2021 HRMARS

Generated

Revenue

$\begin{array}{lll}I G R_{2} & 5.603 & 0.357 \\ I G R_{3} & 4.690 & 0.680 \\ I G R_{4} & 6.476 & 0.476 \\ I G R_{5} & 4.633 & 0.564\end{array}$

Source: Extracted from SPSS (2019) version 20.0

\section{Empirical Result}

For the purpose of achieving the specific objectives of the study, research hypotheses that were initially formulated in line with the general and specific objectives of the study were tested accordingly. These hypotheses were tested by the researchers with the mind set of examining the effect of electronic tax system on internal revenue generation. Linear multiple regression method anchored on ordinary least square (OLS) was employed in testing the hypotheses of the study and the as presented in Table 2 were obtained.

Table 1: Regression Results

\begin{tabular}{lllll}
\hline Variables & Std. Error & BetaCoefficients & t. stat. & Prob, \\
\hline Constant & 0.426 & - & 9.575 & 0.000 \\
Sum-Electronic Tax Reg. & 0.780 & 0.200 & 1.678 & 0.097 \\
Sum-Electronic Tax fil. & 0.109 & -0.275 & -2.348 & 0.021 \\
Sum-Electronic Taxpay & 0.132 & -0.168 & -1.330 & 0.107 \\
T-stat. & & 2.01 & &
\end{tabular}

Source: SPSS Statistics version 20.0

R- squared $=0.887$

R- Squared adjusted $=0.879$

Durbin Waston $=1.516$

\section{Empirical Findings and Discussion}

\section{Electronic tax registration and internally generated revenue in the emerging economy}

The result of hypothesis one (1) indicates that the probability value is 0.097 with the corresponding t-value of 1.678. In line with the decision rule guiding the study, the P-value of hypothesis one falls within the acceptable range of $10 \%$. Based on the result it implies that electronic tax registration significantly affect internal revenue generation in the Nigerian emerging economy drawing reference from Ebonyi state Board of internal revenue. The result of this study is in conformity with the findings of Bett and Yudah (2017), who examine the contribution of i-tax system as a strategy for revenue collection in Kenya revenue authority. Result of the study revealed that online registration of 
INTERNATIONAL JOURNAL OF ACADEMIC RESEARCH IN ACCOUNTING, FINANCE AND MANAGEMENT SCIENCES

Vol. 11, No. 2, 2021, E-ISSN: 2225-8329 @ 2021 HRMARS

taxpayers has a significant contribution on the revenue collection in Kenya. Similarly, the finding of this study is also in agreement with the result of Metinet al (2017), who explored the effect e-taxation system on tax revenue and cost of collection in Turkey. The result showed that transition to the electronic tax system positively affected the tax revenues and reduced the cost per tax. The findings of this study is also in conformity with the findings of Ajapeet al (2017), who empirically investigated the influence of e-tax system on tax administration and tax revenue generation in Lagos State. The major findings revealed that e-tax system has enhanced revenue generation potentials of Lagos.

Electronic filing of tax returns and internally generated revenue in the emerging economy: The result of hypothesis two showed that the probability value (P-value) is 0.021 . Therefore, electronic filing of tax returns has negative significant effect on internal revenue generation in the emerging economy. The negative sign can be seen in the t-value (-2.348). The finding of this research is in line with the result of Obert et al (2018) who evaluated the effect of e-filing on tax compliance in Zimbabwe. The result revealed that electronic filing actually influenced tax compliance. The result of this study is also in conformity with the findings of Bett and Yudah (2017) that online tax return processing has a significant contribution on revenue collection at Kenya revenue authority. In a similar way, the result of this study is in line with the findings of Wasao (2014) who found that online system of taxation do affect tax compliance level among small taxpayers in the east of Nairobi as far as registration, filing and payment were concerned. Secondly, that a unit increase in tax filing would lead to an increase in tax compliance.

The finding of this work also agreed with the result of Obara and Nangih (2017) that the problems of lack of reliable tax database and the prevalence of cash transactions impeded government revenue generation in Nigeria.

\section{Electronic tax payment and internally generated revenue in the emerging economy}

The result recorded in hypothesis three indicated that the P-value is 0.107 with the corresponding tvalue of -1.330 . Going by this empirical result, the researcher rejected the alternate hypothesis. This means that electronic tax payment has no significant effect on internal revenue generation in emerging economy using Ebonyi State in Nigeria as case. The negative t-value implies a negative effect on internal revenue generation. The finding of this study is not in line with the result of Ngigi (2015) who established that the amount of fines and penalties paid and tax consulting or filing expenses have significant relationship with tax compliance.

\section{Conclusions and Recommendations}

The study evaluated the effect of electronic tax system on the internal revenue generation in Nigeria emerging economy using Ebonyi State as a case in point. Governments today are under an increasing pressure to improve on the delivery of public services in cost - effective way. There is a serious decline in price of oil in recent time which has led to a decrease in the funds available for distribution to the state government. As such, the need for state government to generate adequate revenue from internal sources has therefore become a matter of extreme urgency and importance. To meet this challenge for example, tax authorities have adopted e-government led solutions like electronic tax system for the purpose of increasing IGR. The study therefore concludes that the main objective of electronic tax system cannot be achieved in EBSBIR until the effects of electronic tax filing and electronic tax payment are adequately addressed. The implication is that though electronic tax 
INTERNATIONAL JOURNAL OF ACADEMIC RESEARCH IN ACCOUNTING, FINANCE AND

MANAGEMENT SCIENCES

Vol. 11, No. 2, 2021, E-ISSN: 2225-8329 @ 2021 HRMARS

registration has been deployed by EBSBIR; but enhancement in internally generated revenue of the board cannot be guaranteed unless electronic filing of tax returns and electronic tax payment are properly deployed. In line with the findings, the researchers made the following recommend that the emerging economy should legalize the electronic tax system.

Again, a user friendly system should be adopted to encourage easy filing of tax returns in an emerging economy.

\section{References}

Abdulrazaq, A. O. (2015). Overview of FIRS electronic tax filing and online payment of taxes.https://www. Linked in com/pulse/overview-firs- electronic - tax - filing-onlinepayment-taxes - Abdulrazaq .

Abiola, G. A., and Ehigiamusoe, U. K. (2014). Analysis of internally generated revenue and its implications on fiscal viability of states governments in Nigeria: Journal of empirical economics, 2(3), $216-228$.

Adegbie, F. F., and Fakile, A. S. (2011). The impact of tax administration on government revenue in a developing economy: A case study of Nigeria. International journal of business and social science, $3(8)$.

Adenugba, A. A., and Chike, F. O. (2013). The effect of internal revenue generation on infrastructural development: A study of Lagos state internal revenue service. Journal of education and social research, 3(2), $419-436$.

Afuberoh, D., and Okoye, E. (2014). The impact of taxation on revenue generation in Nigeria: International journal of public administration and management research, 22-47. Online at http://www.rcmss.com.

Agrawal M. (2016) E filing of return.The charted accountant, May 1567-1573.

Aguolu, O. (2004). Taxation and tax administration in Nigeria ( $3^{\text {rd }}$ edition). Enugu:Meridan associates.

Ajape, K. M., Afara, A. E., and Uthman, B. A. (2017). The influence of E-tax system on tax administration and tax revenue generation in Lagos state internal revenue service: Journal of economics and business research No. 2, p 129-150.

Alake, S. F., and Olatunji, V. A. (2012). Impact of electronic taxation on tax evasion and avoidance in Nigerian banks: International journal of current research in multidisciplinary, Vol.2, Issue 2. online at http://www.ijcrm.com.

Amitabh, O., Shailendra, P., and Gupta, M. P. (2008). A model for impact of E-government on corruption: Exploring theoretical foundations, critical thinking in E-governance, Available at: https://www.researchgate.net/publication/228369790.

Andrarias, R. (2006). Technology and tax administration: The case of SUMA.Paper presented at the European and Mediterranean conference on information systems (EMCIS), July $6-7$, Spain.

Angahar, P. A. \& Alfred, S. I. (2012).Personal income tax administration in Nigeria.Challenges and prospects for increased revenue generation from self-employed persons in the society-global business and economics research journal, 1 (1), 1-11.

AryaM . (2012). "E - taxation: State and perspective" Cited in H. I Adebowale, "E- taxation in Nigeria: Issues and challenges" (2012) I.T . L.Y. N. 160, 162

Asaolu, T. O., Dopemu, S. O., and Unam, J. M. (2015). Impact of tax reforms on revenue generation Lagos state: Research journal of finance and accounting, 85 - 95 . online at http://www.iiste.org. 
INTERNATIONAL JOURNAL OF ACADEMIC RESEARCH IN ACCOUNTING, FINANCE AND

MANAGEMENT SCIENCES

Vol. 11, No. 2, 2021, E-ISSN: 2225-8329 @ 2021 HRMARS

Asuquo, R. G. (2016). Tax system in Nigeria retrieved on 29/05/16 from www vanguard media.com

Balogun, A. (2015). Developing internally generated revenue in an era of diversification.online at https://www.vang4ardngr.com.

Bett, B. K., and Yudah, O. A. (2017). Contribution of integrated tax system as a strategy for revenue collection at Kenya revenue authority: International journal of scientific and research publications, 389-396 online at www.ijsrp.org.

Braithwaite, V. (2009).Defiance in taxation and governance. Resisting and dismissing authority in democracy, Edward Elgar, Cheltenham.

Chandler B. M. (2013).The consequence of poor tax administration collections, growth and corruption. Unpublished dissertation of doctor of philosophy, Andrew young school of policy studies, Georgia state university.

Chau, and Leung, P. (2009).A critical review of Fischer tax compliance model. A research synthesis, Journal of accounting and taxation (2) = $034-040$.

Deloitte Nigeriablog. (2017). FIRS introduces six electronic tax services" http://blog .deloitte.com.ng/firs - introduces - six-electronic tax - services.

Dowe, E. D. (2008). E-filing and e-payments - The way forward.Paper presented at the Caribbean organization of tax administration(COTA) general assembly, Belize city.

Ebimobowei, A. E. (2012). The impact of tax reforms on the economic growth of Nigeria: Current research journal of economic theory 4(2), $29-38$.

Emmanuel, M. (2010). Nigerian tax system: entrenching new national tax policy, Nigerian tribune, $p$ 6.

Enahoro, J., \& Olabisi, J. (2012).Tax administration and revenue generation of Lagos state.research journal of finance and accounting.28(13), $110-124$.

Eneojo, S. S., and Gabriel, T. (2014). Taxation and revenue generation: An empirical investigation of selected states in Nigeria: journal of poverty, investment and development, 4(1), $102-115$.

Eric, M. Z., and Richard, M. B. (2008) tax policy in emerging countries. Environment and planning C:government and policy, pp. 73-86, 2008.

Fagbemi, T. O., and Abogun, S. (2010). Factors influencing voluntary tax compliance of small and medium scale enterprises in Kwara state Nigeria.

Fave, K. S., and Dabari, I. J. (2017). The Epirical analysis of tax revenue collection by the federal government in Nigeria: European journal of accounting, auditing and finance research. 5(2), 111.Available at http://www.cajournals.org.

Gwaro, O. T., Maina, K., and Kwasira, J. (2016). Influence of online tax filing on tax compliance among small and medium enterprises in Nakuru town in Kenya: Journal of business and management, 18, (10), 82 - 92. available online at http://www.iorjournals.org.

Harrison, M. N., and Nahashon, K. (2015). Effect of online tax system on tax compliance among small taxpayers in Meru County, Kenya: International journal of economics, commerce and management, 3(12), $283-298$.

Holban, O.(2007). The taxation of small and medium- sized enterprises - a hindering factor influencing the European economic growth doctoral dissertation, Alexandru loan cuza university of lasi and academy of economies studies from Bucharest Romania.

Jayakumar, A., and Nagalakshmi. (2006). Direct tax reforms: An overview, South economist, July, 911. 
INTERNATIONAL JOURNAL OF ACADEMIC RESEARCH IN ACCOUNTING, FINANCE AND

MANAGEMENT SCIENCES

Vol. 11, No. 2, 2021, E-ISSN: 2225-8329 @ 2021 HRMARS

Khadijah, I. (2013). Tax complexities in the malaysian corporate tax system : Minimize to maximize. International journal of law and management 56, pp 50-65

Leyira, O., Chukwuma, K., and Asia, E. I. (2012). Tax system in Nigeria: The challenges and the way forward. Ibadan: spectrum law publishing.

Madegwa, B. L., Makokha, E. N., and Namusonge, G. (2018). Effect of automation of revenue collection on the performance of county government in Kenya: European journal of business and management journal of business and management 11(10), $118-124$.

Maisiba, G. J., and Atambo, W. (2016) Effect of electronic tax system on the revenue authority: Imperial journal of interdisciplinary research, 2,(4). Available online at http://www.pnlinejournal.

Majura, I. W. (2013). Theories of taxation, available online at https://www.academia.edu.

Mararia, K. A (2014). The effect of integrated tax management system on tax compliance by small and medium sized enterprises in Nairobi central business district. (unpublished article)

Metin, A., Ali, A., and Metehan, O. (2017). The effect of electronic taxation system on tax revenues and costs: International conference on accounting studies. available online at www.icgs.my

Monica, F. W., Mkokha, E. N., and Namusonge, G. S. (2017).Effect of electronic tax system on tax collection efficiency in domestic taxes department of Kenya revenue authority.European journal of business and management, 9(17), $19-51$.

Muita, E. W. (2011). Factors that influence adoption and use of electronic filing system of Kenya revenue authority among the large taxpayers: Unpublished MBA project submitted in partial fulfillment of the requirements for the award of the degree of master of business administration (MBA) in finance department, university of Nairobi.

Muturi, H. M., and Kiarie, N. (2015). Effect of online tax system on tax compliance among small taxpayers in meru country, Kenya: International journal of economics, commerce and management. 3,(12), 280 - 297 Available at http://ijecm.co.uk/

National population commission. (2018). nigeria's population hits $198 \mathrm{~m}$ people - NPOPC chairman http : //population.gov.ng/Nigerias - population- hit - 198m - people - npopc - chairman/.

National tax policy(2018)- ch. 5, para.5. I xix

Ndayisenga, E., and Shukla, J. (2016). Effect of electronic tax management system of tax collection in Rwanda: International journal of business management, 4,(5), 38 -49. Available online at http://www.iheijbm.com.

Nelson, G. (2002). Information technology in support of the tax administration functions and taxpayers assistance: A paper presented at the third regional training workshop on taxation, Brazil.

New Man, U. R., and Eghosa, O. E. (2019). Electronic taxation in Nigeria: challenges and prospects. https: //www. Research gate.net/publication/330422913. (International Company and Commercial Law Review).

Ngigi, M. B. (2015). Effect of integrated tax management system on tax compliance by small and medium enterprises in the central business district, Nairobi unpublished research project submitted to the department of finance and accounting, school of business management university of Nairobi in partial fulfillment of the requirement for the award of the degree of master of science (MSC) in finance. 
INTERNATIONAL JOURNAL OF ACADEMIC RESEARCH IN ACCOUNTING, FINANCE AND

MANAGEMENT SCIENCES

Vol. 11, No. 2, 2021, E-ISSN: 2225-8329 @ 2021 HRMARS

Nnanseh, M., and Akpan, S. (2013). Internally generated revenue (igr) and infrastructural development in Akwalbom state. European Journal of Business and Management Studies, 5(31), $164-172$.

Obara, C., and Nangih, E. (2017). Tax compliance barriers and internally generated revenue in nigeria; A study of small and medium enterprises in Port Harcourt metropolis: International Journal of Academic Research in Accounting, Finance and Management Science, vol 7 (4), 169-176. Available Online at http:// dx.doi. org/10. 6007/ IJARAFMS/ V7-14/3481.

Obert, S., Rodgers, K., Tendai, M. J., and Desderio, C. (2018). Effect of e-tax filing on tax compliance: A case of clients in harare, Zimbabwe. Africanjournal of business management, 12(11), 338 342.Online at http://www.academicjournals.org/AJBM.

Odia, J. O. (2014). Factors affecting personal income tax compliance in Nigeria. The official journal of the chartered institute of taxation of Nigeria (CITN), $113-130$.

Ofurum, C. N., Amaefule, L. I., Okonya, B. E., and Henry, C. A. (2018). Impact of e-taxation on Nigerian's revenue and economic growth: A pre-post analysis: international journal of finance and accounting 7(2), $19-26$.

Okoye, V. C., and Ezejiofor, R. (2014). The impact of electronic taxation on revenue generation in Enugu, Nigeria: International journal of advanced research 2,(2), $449-458$. Available Online at http://www.journalijar.com.

Olaoye, C. O. T., and Kehinde, B. A. (2015). Impact of information technology on tax administration in Southwest, Nigeria: Revolution or Evolution. Journal of Social Science, 11(1), 1 - 9.

Olatunji, O. C., and Ayodele, K. B. (2017). Impact of information technology on tax administration in Southwest, Nigeria: archives of business research 5(9), http://dx.doi.org/10.14738/abr.59.3549.

Olotu, G. E. (2012). Welcome address speech by the chairman, chartered institute of taxation of Nigeria (CITN), $4^{\text {th }}$ annual tax conference.

Olurankinse, F., and Oladeji, O. E. (2018).Self-assessment, electronic taxation payment system and revenue generation in Nigeria. International accounting and taxation research group, faculty of management sciences, university of Benin, Benin City, Nigeria p $39-55$. Available online at http.//www.atreview.org.

Omodero, C. O., Ekwe, M. C., and Ihendinihu, J. U. (2018). The impact of internally generated revenue on economic development in Nigeria: Journal of Accounting and Finance Research, 7(2), 166 173. Available Online at https//doi.org/10.5430/9fr.v7n2p166.

Oseni, M. (2013). Internally generated revenue (IGR) in Nigeria: A panacea for state development.European journal of humanities and social sciences, 21(1), 1050-1066.

Oseni, M. (2015). Sustenance of tax administration by information and communication technology in Nigeria: Archives of business research, 4(1), $47-54$.

Owino, H. O., Otieno, S., and Odoyo, F. S. (2017). Influence of information and communication technology on revenue collection in county government in Kenya: International journal of

PWC. (2013).The making of a good e - tax system - www.pwc com/ng.

Ramayah, T., Romoo, V., and Amlmus, I. (2008). Profiling online and mammal tax filers: results from an exploratory study in penang, Malaysia. Labuan e-journal of manmalat and society, 2, 1-8.

Rubin, A, and Babble, E. R (2005). Research methods for social work.published by Australia Belmont C.A: Thomson/brooks/cole . 
INTERNATIONAL JOURNAL OF ACADEMIC RESEARCH IN ACCOUNTING, FINANCE AND

MANAGEMENT SCIENCES

Vol. 11, No. 2, 2021, E-ISSN: 2225-8329 @ 2021 HRMARS

Tan, L., and Sawyer, A. J. (2003). A synopsis of taxpayer compliance studies: Verviewvis - vis New Zealand.New Zealand journal of taxation and law policy, 9 (4), 431 - 454.

Tanko, M., Okpara, E., and Ajape, K. M. (2013).The correction between multiple taxations and tax evasion, tax avoidance and taxpayers' obligation in Lagos State, Nigeria.International journal of business, accounting and finance, $7(2), 138-146$.

Teltsher, S. (2002). Electronic Commerce and development: Fiscal implications of digitised goods trading. Journal of world development, 30,(7).

Umenweke, M. N., and Ifediora, E. S. (2016). The law and practice of electronic taxation in Nigeria: The gains and challenges: NnamdiAzikiwe university Journal of international law and jurisprudence (NAUJIL), $101-112$.

Uremadu, S. O., and Ndule, J. C. (2011). A review of private sector tax revenue generation at local government level: Evidence from Nigeria, Journal of public administration and policy research, 3 (6), 174-183.

Usman U. Y. (2013). The ITAS solution gathers momentum. Gauge (quarterly publication of the federal inland revenue service) (January - March 2013) $p-8$.

Vanguard Newspaper (2017).FIRS introduces 6 online tax solutions. https://wwwvangurdngr.com/2017/06/firs introduces 6 - online - tax - solutions.

Wang, L. (2010). A review of the determinants of voluntary compliance with tax laws by south african taxpayers with particular reference on businesses in South Africa. unpublishedmphil. Taxation mini-dissertation, university of Pretoria.

Wasao, D. (2014). The effect of online tax system on tax compliance among small taxpayers in east of nairobi tax district in Kenya: Unplished dissertation submitted in partial fulfillment of the requirements for the award of the degree of master of science (m.sc) in finance department of university of Nairobi, Kenya.

World bank and price water house coopers (2013). paying taxes report. world bank group. available online at http://www.pwc.com/gx/en/paying-taxes/pgf/pwc-paying-taxes-2013-pdf. 